\title{
Basal debris entrainment and transport in glaciers of southwestern Bylot Island, Canadian Arctic
}

\author{
C. M. ZDANOWICZ, \\ Glacier Research Group, Morse Hall, University of New Hampshire, Durham, NH 03824-3589, U.S.A. \\ F. A. MicheL, \\ Department of Earth Sciences, Careleton University, Ollawa, Ontario, K1S.5B6, Canada \\ W. W. SHILTS \\ Illinois Geological Survey, 615 East, Peabody Drive, Champaign, IL 61820-6964, U.S.A.
}

\begin{abstract}
Glaciers on southwestern Bylot Island in the Canadian Arctic flow from an alpine setting in high-grade crystalline Archean terrane, on to coastal lowlands underlain by clastic sedimentary strata of Cretaceous to Tertiary age. We have used the contrasting mineralogy of the substrate as a tool to study subglacial entrainment and transport of debris in two large piedmont glaciers on Bylot Island. High chlorite/ and mica-illite/smectite ratios indicate that most basal debris is derived from crystalline rocks underlying the upper reaches of the glaciers. The subglacial accretion of Cretaceous-Tertiary sediments appears restricted to the lowermost part of the basal zone and is most noticeable near the glaciers' termini. Ice associated with discrete silty sandy debris layers is characterized by an isotopic signature indicative of refreezing of meltwater at the glacier sole. The compositional, textural and isotopic characteristics of basal sediment and ice lead us to conclude that subglacial entrainment through basal ice accretion occurs in both the upper and marginal parts of the glaciers.
\end{abstract}

\section{INTRODUCTION}

Most existing models for deposition of glacial diamictons emphasize the physical attributes of sediments, which are largely governed by when and where the sediments were released from ice. Yet the composition of tills may also be controlled by physical partitioning accompanying sediment acquisition and transport (Boulton, 1970). Here we present results from a field investigation on southwestern Bylot Island in the Canadian Arctic, in which we aimed to elucidate processes of basal debris entrainment and transport by using a simple compositional constraint to relate the debris load of glaciers with specific bedrock sources. To this end, we examined the spatial distribution of mineralogically distinct sediments in the basal zone of two large glaciers using X-ray diffraction techniques. In addition, the isotopic composition of debris-rich basal ice was analyzed for indications of entrainment processes involving freezing of water at the glacier sole.

\section{GEOLOGICAL AND GLACIOLOGICAL SETTING}

Bylot Island $\left(11067 \mathrm{~km}^{2}\right)$ is nestled on the northeast corner of Baffin Island at the entrance to Lancaster Sound (Fig. la). The Byam Martin Mountains, with peaks averaging $1400 \mathrm{~m}$ a.s.l., rise from the island's core. To the southwest, smooth, gently rolling hills extend from the piedmont to the shores of Eclipse Sound and Navy Board Inlet. A $4900 \mathrm{~km}^{2}$ ice field occupies the mountains, feeding several hundred glaciers, some of which stretch up to $20 \mathrm{~km}$ away from their main cirque.

The Byam Martin Mountains are underlain by highgrade crystalline rocks of Archean to Aphebian age. Associated lithologies are migmatites of granitic to granodioritic composition, interspersed with some supracrustal metasedimentary and metavolcanic sequences (Jackson and others, 1975). A southeast-trending fault zone marks the transition between the central highlands and coastal lowlands, and identifies the discordant contact of the Precambrian uplands with the Cretaceous-Tertiary sedimentary strata underlying the Bylot Lowlands. The latter consist of a sequence of poorly consolidated sandstones and mudstones derived from the Precambrian highlands and deposited in the faultcontrolled Eclipse Trough basin (Miall and others, 1980).

The study area $\left(73^{\circ} \mathrm{N}, 79^{\circ} \mathrm{W}\right)$ encloses several major glaciers flowing to the southwest over the Byam Martin foothills and on to the Bylot Lowlands (Fig. 1b). These glaciers incorporate a mixture of debris eroded from lithologically contrasted sources, thus providing a compositional constraint that may be used to trace the 


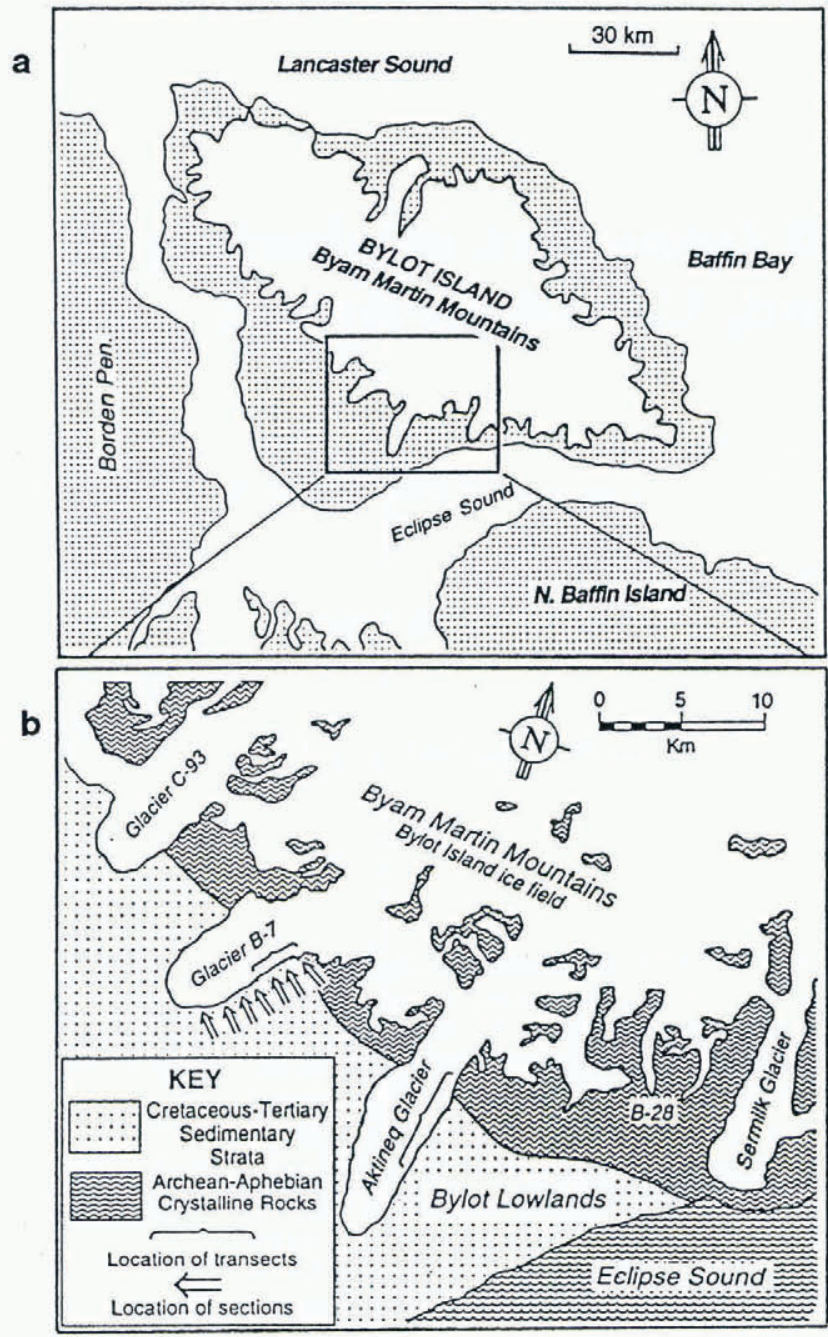

Fig. 1. (a) Location map, Bylot Island, eastern Canadian Arctic. (b) Enlargement of the study area on southwestern Bylot Island, showing the major glaciers flowing over the Archean-Aphebian and Cretaceous-Tertiary terranes. Simplified geology after Jackson and others (1975).

pattern of entrainment, mixing and transport of the basal debris load. In addition, the high (up to $60 \mathrm{~m}$ ), nearvertical margins of these outlet glaciers offer excellent exposure of their internal structure and stratigraphy.

\section{PRINGIPAL FEATURES OF GLACIERS}

Our data were compiled from two major glaciers flowing across the crystalline and sedimentary terranes: Aktineq and B-7 Glaciers. In both glaciers, the bulk of the sediment load is transported in the basal zone as a layered sequence of ice and debris $6-8 \mathrm{~m}$ thick on average. This zone thickens near the glaciers' termini as a result of compressive flow, folding and thrusting (Lorrain and others, 1981; Klassen, 1993). Supraglacial debris is in the form of coarse, angular erratics derived up-glacier from valley walls and nunataks by mass wasting. Visual evidence suggests that some of the basal debris may be brought up along shear planes from the basal to the englacial and supraglacial zones.

Despite their proximity and comparable bulk, there are striking differences between Aktineq and B-7 Glaciers.
Aktineq Glacier carries a significantly greater load of basal sediment than Glacier B-7. Measurements of sediment volume concentrations in several basal layers of Aktineq Glacier gave an average of $22 \%$, while similar layers in Glacier B-7 yielded about half this value $(R$. DiLabio and W. Shilts, unpublished data). Aktineq Glacier also appears to contain a greater proportion of sand-size and coarser debris (average 92\% weight) than does Glacier B-7 (75\% weight).

The basal zone of Aktineq Glacier includes a lower, relatively thin $(1-2 \mathrm{~m})$, massive to crudely stratified debris-laden facies, which grades into a thicker (up to $6 \mathrm{~m}$ ) banded facies with silty to sandy sediment concentrated in thin discrete layers. The ice morphology was described by Lorrain and others (1981) as consisting mostly of coarse to monocrystalline bubble-free ice. On Glacier B-7, the basal zone displays an 8-12 $\mathrm{m}$ high sequence of coarse-grained bubble-free ice with dispersed aggregates of silty sediment. Numerous thin $(1-3 \mathrm{~cm})$ dirty-ice layers containing silt- to sand-sized debris occur at irregular intervals throughout this sequence. The debris-laden ice exposed at the base of Aktineq Glacier may correspond to the stratified facies described by Lawson (1979). Similarly, the thick basal ice sequence on Glacier B-7 presents features similar to those of Lawson's dispersed facies. However, this similitude does not extend to all features of Aktineq and B-7 Glaciers. Thus, on Glacier B7 the stratified facies was rarely observed, except close to the terminus where it was exposed at a significant thickness.

The marked contrast between the basal debris load of Aktineq and B-7 Glaciers is most likely related to their respective drainage patterns. Aktineq Glacier flows over a distance of nearly $35 \mathrm{~km}$ and is fed by over 15 tributaries, whereas Glacier B-7 stretches over $20 \mathrm{~km}$ and is fed through only six major tributaries. It follows that much of the debris transported in the basal zone of Aktineq and B7 Glaciers must have been acquired over the alpine uplands. Boulton (1978) suggested that zones of compressive ice flow, as found at the confluence of tributaries or on the lee side of a bedrock spur, may be favorable sites for the upward entrainment of debris into overflowing ice.

\section{SAMPLING AND ANALYTICAL STRATEGY}

In a previous study of Bylot Island glaciers, DiLabio and Shilts (1979) observed that the textural and mineralogical immaturity of sand-sized debris derived from the Cretaceous-Tertiary substrate did not allow clear differentiation from that derived from Archean crystalline rocks. We chose instead to analyze spatial variations in the clay mineralogy of the sediment. To this effect, samples of basal debris were collected on several vertical profiles along the eastern margin of Glacier B-7, and on two transects along the margins of Aktineq and B-7 Glaciers (Fig. 1b). Sampling sites were chosen to provide maximum spatial coverage of the basal zone both upglacier and down-glacier of the contact between the crystalline and sedimentary terranes. The sediment sampled along vertical profiles on Glacier B-7 was associated with the discrete dirty-ice layers exposed throughout the basal zone. There is no direct correlation 
between layers from profile to profile, as most are laterally discontinuous. The debris sampled along the marginal transects was collected in the lowermost exposed part of the basal zone, as close to the glacier bed as possible. Due to the abundance of slumped material, the recognition of basal ice facies was ambiguous in most cases.

The samples were wet-sieved and the clay $(<2 \mu \mathrm{m})$ fraction was isolated by decantation and centrifugation, following the methodology of Berry (1987). Weight percentages for the silt and clay fraction were determined with a precision of $\pm 0.01 \%$. Volumetric particle-size analyses were also performed on selected samples, using a Brinkman laser analyzer in the Geological Survey of Canada laboratories. The techniques for X-ray diffraction (XRD) analysis were adapted from Carroll (1970). Clay samples were drop-mounted on glass slides and scanned at room conditions prior to and after saturation with ethylene glycol vapour, on a Phillips Norelco diffractometer using monochromatic $\mathrm{Cu} \mathrm{K} \alpha$ radiation.

The remarkable consistency of XRD patterns obtained from over 160 samples of basal sediment allows for a breakdown of the clay mineralogy into principal components, identified by their characteristic crystallattice spacings: chlorite ( $14 \AA$ reflection), chlorite and/or kaolinite $(7 \AA)$, micas and/or illite $(10 \AA)$, and smectite and/or mixed-layer expansible clays $(17 \AA)$. In order to quantify the spatial variations of these constituents, we computed intensity ratios for the major XRD peaks of each sample. For example, a change in the abundance of smectites relative to that of micas is expressed by a change in the intensity ratio of the 17 to $10 \AA$ reflections. This approach is sensitive to instrumental variability and involves a degree of subjectiveness in estimating peak intensities (Griffin, 1971). Yet duplicate analyses showed a precision of $\pm 15 \%$ on computed ratios, which was judged adequate for our goals.

\section{TEXTURE AND MINERALOGY OF BASAL SEDIMENTS}

The clay fraction of basal debris from Aktineq and B-7 Glaciers consists of a mixture of well-crystallized micas (biotite, muscovite) and chlorite, with lesser amounts of illite, smectite (montmorillonite) and other swelling clays. Chlorites and micas are common primary clay-sized components in tills derived from crystalline basement rocks, and are thought to originate from the ArcheanAphebian uplands of Bylot Island. DiLabio and Shilts (1979) suggested the expansible clays were most likely derived from the erosion of fine-grained clastic sedimentary rocks of the Cretaceous-Tertiary terrane.

To verify this contention, we compared the XRD signatures of glacial clay samples with those obtained from mechanically pulverized bedrock specimens collected in the study area. Our results indicate that typical clay-sized minerals associated with the Archean migmatites include biotite, muscovite and minor kaolinite, while smectite, illite, vermiculite and kaolinite dominate the clay suite of Cretaceous-Tertiary sandstones and siltstones. Minor amounts of smectite and other mixed-layer clays were also identified in some crystalline rocks; they may represent secondary products of hydrothermal alteration along fractures and joints in the basement rocks (Velde, 1985).

Figure 2 a shows variations in the relative abundance of identified clay species in basal debris along the eastern margins of Aktineq and B-7 Glaciers, plotted against cross-sections of the substrate (Fig. 2c). On Aktineq Glacier a marked increase in the ratio of swelling clays $(17 \AA)$ to other components is observed immediately down-glacier from the faulted geological contact. This is interpreted as reflecting the subglacial entrainment of smectite-rich material derived from the underlying mudstones of the Kanguk Formation $\left(\mathrm{Kk}_{1}\right)$. Further down-glacier the $17: 14$ and $17: 7 \AA$ ratios decrease gradually, although the trend is subtle. A gradual down-glacier increase in the proportion of basal claysized debris is also noticeable along that part of the glacier flow-path stretching over the Kanguk mudstones Fig. 2b). This pattern terminates abruptly with the flow of ice over the coarser-grained sandstones of the upper Kanguk Formation $\left(\mathrm{Kk}_{2}\right)$.

The pattern of textural and mineralogical variations in debris along the margin of Glacier B-7 is more obscure. A down-glacier, stepwise increase in the proportion of fines of the basal debris load is evident (Fig. 2b). As well, a moderate increase in the ratios of swelling clays to micas and chlorite can be observed over the faulted zone. But more remarkable is the high concentration of $17 \AA$ clavs relative to chlorite up-glacier of the contact, which suggests the presence of a source of swelling clays over the crystalline substrate. On nearby Aktineq, Sermilik and B-28 Glaciers, high levels of smectite and kaolinite were also found in some supraglacial debris samples derived from source outcrops well into the Archean uplands. Such anomalies cannot be accounted for solely by the minor presence of alteration minerals in the crystalline substrate. We propose instead that they reflect the subglacial recycling of ancient drift deposited far inland during episodes of regional glaciation.

The Quaternary geological record of Bylot Island reveals several periods of glaciation by regional ice sheets that advanced onto the island, as well as by expanding local ice caps (Klassen, 1985). In the study area, exotic drift is mostly associated with the Middle Wisconsinan Eclipse regional glaciation, and consists of a discontinuous cover of sandy diamicton containing variable amounts ( $1 \%$ to $>80 \%$ weight) of material derived from Paleozoic and Proterozoic carbonate rocks on northeastern Baffin Island Klassen, 1993; McCuaig, 1994). Thus, it is conceivable that the smectite-rich debris carried in ice flowing out of the Archean uplands was derived from a veneer of exotic drift deposited inland during previous regional glacial episodes. This circumstance demonstrates how any inference of basal debris provenance based on a compositional constraint must be regarded with caution. In this case, the presence of expansible clays in the basal debris load of glaciers cannot be linked unequivocally with a Cretaceous-Tertiary bedrock source.

Figure 3 shows spatial compositional variations in debris along the margin of Glacier B-7, as observed in seven vertical profiles (VS1-7). The profiles are tentatively correlated using the well-defined contact between the basal and englacial zones as a reference horizon. The presence of moraines did not allow basal debris to be 


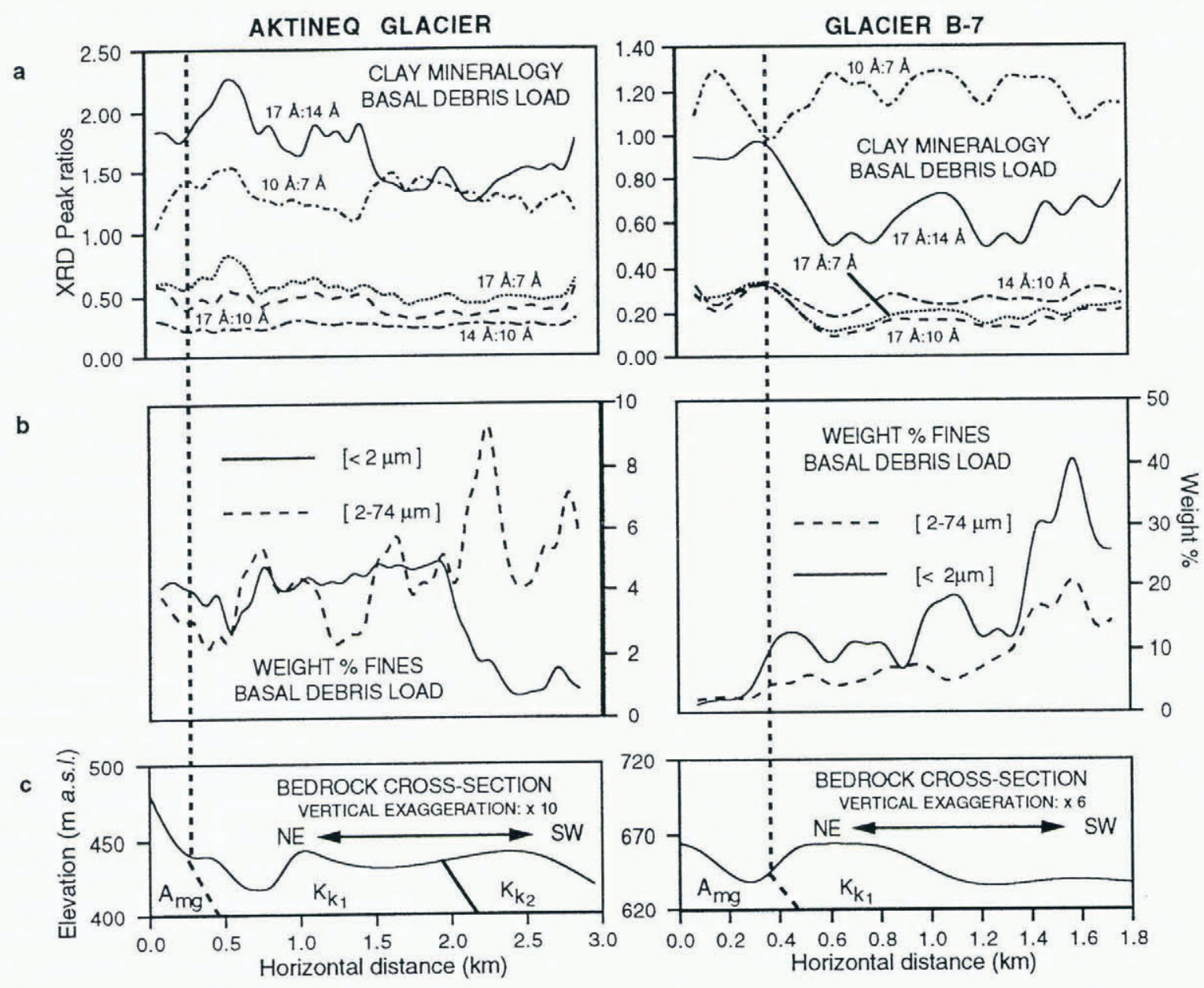

Fig. 2. Longitudinal transects along the eastern margins of Aktineq and B-7 Glaciers, showing (a) compositional (XRD clay mineral ratios) and (b) textural (weight \% clay) variations in basal debris, plotted against (c) cross-sectional topographic profiles of the underlying substrate. Ice flow is from left to right. The XRD ratios are interpreted as follows: $17 \dot{A}=$ smectite; $14 \hat{A}=$ chlorite $; 10 \AA=$ micas + illite; $7 \AA=$ chlorite and $/$ or kaolinite. Simplified geology after Miall and olhers (1980). The dolled line denotes the faulted contact between Archean-Aphebian migmatites (Amg) and Cretaceous mudstones $\left(K k_{1}\right)$ and sandstones $\left(K k_{2}\right)$. Location of the transects is shown in Fig. 16 .

sampled on the lowermost part of profiles VS2, VS3, VS5 and VS7.

The abundance of swelling clays relative to that of chlorite shows no clear pattern of variation in the basal zone of Glacier B-7. Hence, there does not appear to be any systematic down-glacier enrichment by smectites from the Cretaceous substrate. This may imply either that such an enrichment does occur but is not accurately reflected in the $17: 14 \AA$ ratio, or (more likely) that most sediments in the basal zone of Glacier B-7 are not entrained locally under the piedmont lobe, but are derived instead from the upper reaches of the glacier bed.

The only sites where compositional evidence supports the basal accretion of debris from the CretaceousTertiary strata are found near the frontal margins of Aktineq and B-7 Glaciers. For instance, a marked enrichment of swelling clays relative to micas has been observed along a basal ice profile near the terminus of Aktineq Glacier (DiLabio and Shilts, 1979, fig. 4, profile 2 ). Sites where such an enrichment occurs coincide with those where thick debris-laden basal ice layers are exposed. These layers display features such as rafts of frozen, undeformed sediments incorporated within a dirty-ice matrix (DiLabio and Shilts, 1979).
Such features appear consistent with the accretion of subglacial debris by net freeze-on. However, to operate this process requires a supply of meltwater at the glacier sole, and the coexistence of an inner warm-based and an outer cold-based zone at the ice margin (Weertman, 1961). We have observed muddy water spurting out of conduits along the margins of both Aktineq and B-7 Glaciers. The abundance of suspended fines suggests that this water flowed near the ice/bedrock interface, where most fines are produced by physical comminution Haldorsen, 1981). The water may originate from internal melting or be supplied to the glacier bed from surface melt through moulins and crevasses. Lorrain and others (1981) have shown from isotopic evidence that both sources probably contribute to the formation of basal ice on Aktineq Glacier. Furthermore, the presence of meltwater-derived basal ice may be suggestive of the existence of unfrozen regions at the bed (Klassen, 1993). This does not exclude the possibility of sediment entrainment through other processes, such as regelation in underlying debris (Iverson, 1993). Observations in an abandoned channel underneath nearby Glacier B-28 also showed that sandy debris is being incorporated into overlying ice by freezing onto the channel roof. 
Archean-Aphebian substrate

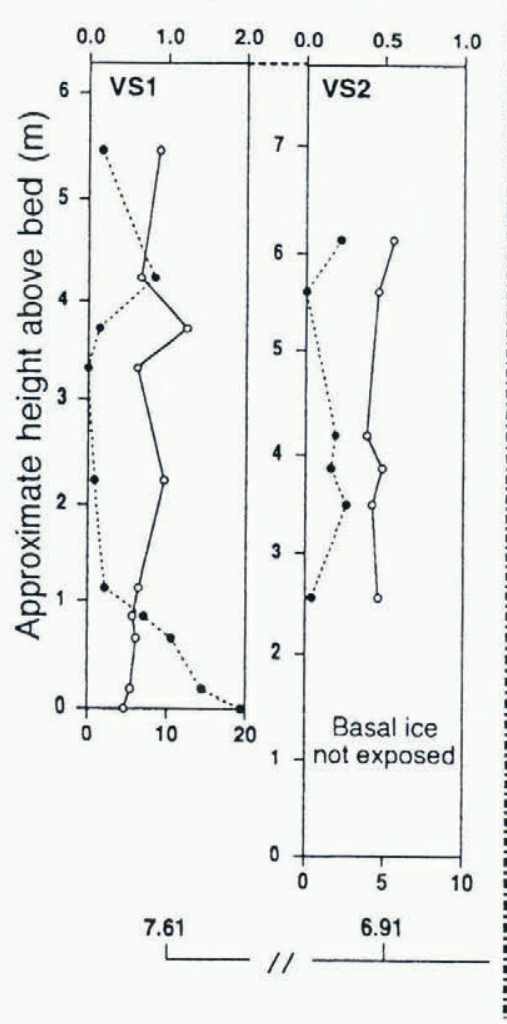

Cretaceous-Tertiary substrate

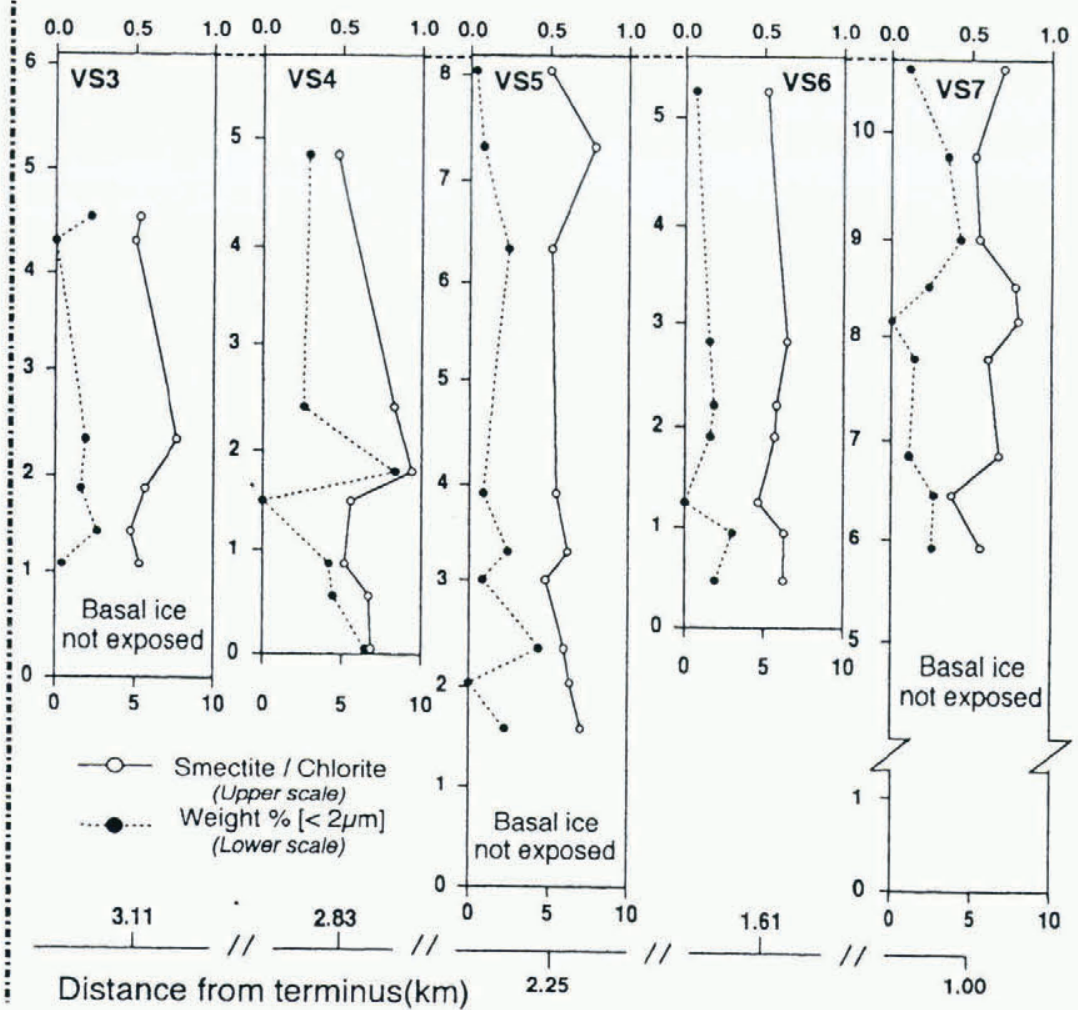

Fig. 3. Vertical profiles, showing compositional (smectite-lo-chlorite ratio) and textural (weight \% clay) variations in basal debris along the eastern margin of Glacier B-7. Profiles are correlated along the basal-englacial zone transition (top) and arranged from up-glacier (VS1; right) to down-glacier (VS7; left). The location of each profile relative to the glacier terminus is shown on the bottom scale. The faulted geological conlact (dotted line) underlies the ice margin between profiles VS2 and VS3. See text for details and interpretation.

If net freeze-on does occur beneath glaciers of Bylot Island, it is most likely restricted to their marginal zone (Weertman, 1961). One or more other mechanisms must then account for the entrainment of the discrete basal dirty-ice layers found in the up-glacier regions of Aktineq and B-7 Glaciers. The texture of the sediment carried in these layers is typically fine, averaging nearly $25 \%$ weight of silt- and clay-size particles: we see this as suggestive of a subglacial origin. Indeed, the mode of the particle-size distribution of debris in the $2-300 \mu \mathrm{m}$ range was found to be nearly identical to that produced by artificial abrasion of local bedrock samples.

\section{ISOTOPIC GHARACTERIZATION OF BASAL ICE}

To further our investigations, we have applied the coisotopic method of Jouzel and Souchez (1982) to investigate ice samples from the discrete sediment-bearing layers of Glacier B-7. This method is based on the premise that basal ice formed by refreezing of meltwater in a closed system is characterized by a $\delta \mathrm{D}: \delta^{18} \mathrm{O}$ gradient significantly lower than that of the local meteoric water line $(\mathrm{MWL} ; \approx 8)$ as a result of the different isotopicequilibrium fractionation coefficients of hydrogen and oxygen during freezing of water. Lorrain and others (1981) previously established that monocrystalline ice associated with sandy layers at the base of Aktineq Glacier displayed such an isotopic signature. Here we have adopted the same approach to examine the discrete silty-sandy layers in Glacier B-7.

Ice within the layers is typically coarse-grained to monocrystalline, with elongated sinuous inclusions of silty-to-sandy sediments. This aspect is comparable to that commonly associated with regelation ice Hubbard and Sharp, 1989). The ice was sampled at a depth of 15 $20 \mathrm{~cm}$ from the surface to avoid isotopic contamination by surface runoff. Samples were allowed to melt and were transferred into airtight polyethylene vials that remained frozen until analysis. The hydrogen -deuterium composition was determined by extraction of $\mathrm{H}_{2}$ gas via zinc reduction at $430^{\circ} \mathrm{C}$, and the oxygen-isotope ratio obtained by $\mathrm{CO}_{2}$ water equilibration at $25^{\circ} \mathrm{C}$ using a fractionation factor of 1.0412. Measurements were performed on multiple collector VG-SIRA mass spectrometers. Results are expressed in $\delta$ units normalized to SMOW. The routine analytical precision $(2 \sigma)$ is of $\pm 1.3 \%$ for $\delta \mathrm{D}$, and $\pm 0.10 \%$ for $\delta^{18} \mathrm{O}$.

The $\delta \mathrm{D}$ and $\delta^{18} \mathrm{O}$ values of 15 basal ice samples selected from the vertical profiles examined on Glacier B-7 are plotted in Figure 4. The scatter of data may be in part related to internal isotopic variability within the sampled layers (Hubbard and Sharp, 1993). A leastsquares cubic spline was fitted to the data Burn and Maxwell, 1992) and gave a slope of 4.4 for the $\delta \mathrm{D}-\delta^{18} \mathrm{O}$ linear relationship. We compared this result with a gradient of 7.8 for the local MWL, as calculated from firn and glacier ice sampled in the accumulation zone of 


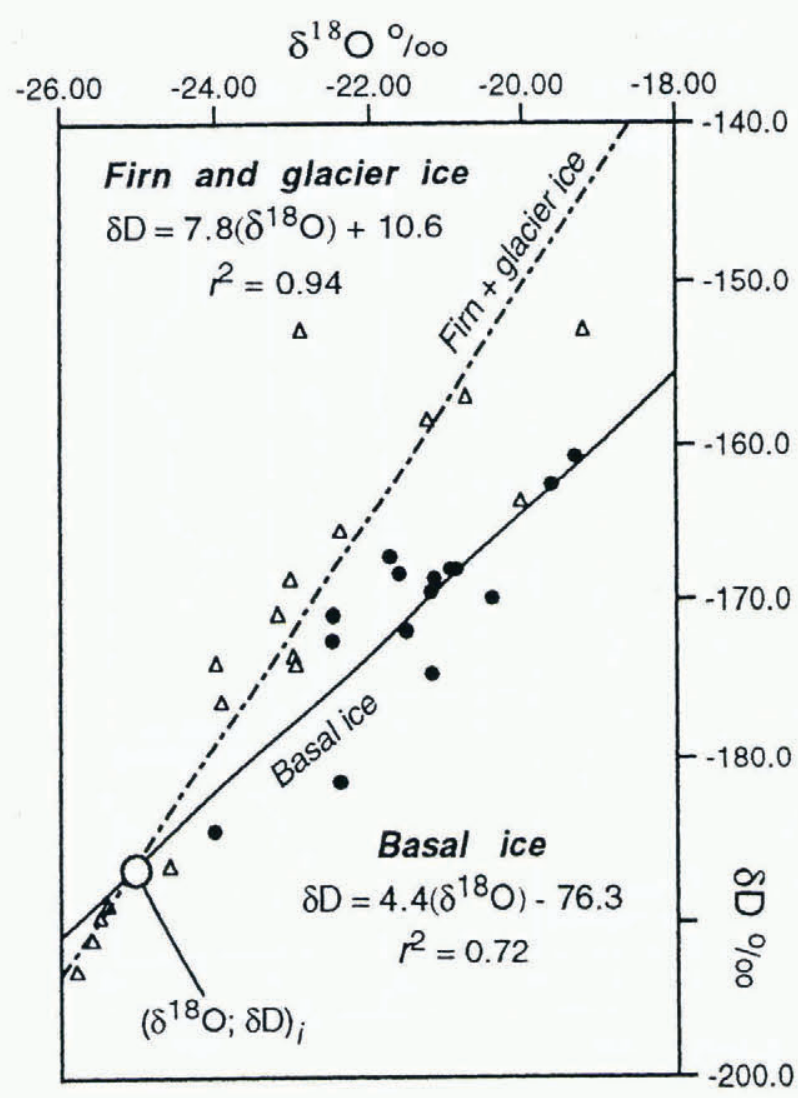

Fig. 4. $\delta^{18} O-\delta D$ relationships in firn/glacier ice (open circles) and in debris-rich basal ice (full circles) from Glacier B-7. The intersection of the two cubic-regression splines gives the initial average composition $\left(\delta^{18} O ; \delta D\right)_{\mathrm{i}}$ of the meltwater from which the basal ice refroze.

the glacier (Fig. 4). Both the 4.4 and 7.8 figures compare well with those obtained by Souchez and others (1988) from the same site, and with those from other sub-polar glaciers (e.g. Sugden and others, 1987; Gordon and others, 1988; Knight, 1989).

The slope of 4.4 for the $\delta^{18} \mathrm{O} \delta \mathrm{D}$ relationship of basal ice from Glacier B-7 is suggestive of a melting-refreezing origin at the glacier sole. The intersection $\left(\delta^{18} \mathrm{O} ; \delta \mathrm{D}\right)_{\mathrm{i}}$ of the MWL and basal ice line allowed us to calculate the theoretical freezing slope, i.e. the slope of the $\delta \mathrm{D}-\delta^{18} \mathrm{O}$ relationship for ice formed by the refreezing of a finite water volume of initial composition $\left(\delta^{18} \mathrm{O} ; \delta \mathrm{D}\right)_{\mathrm{i}}$ (Souchez and Jouzel, 1984). Results of our calculations show that the slope of the basal ice line (4.4) differs somewhat from the theoretical freezing slope of 5.8 , but is still significant at a $90 \%$ level of confidence.

These results, along with the fine texture of the transported sediment, lead us to suggest that the discrete, debris-bearing layers found in basal ice on Glacier B-7 originated through a process involving subglacial accretation of debris by melting-refreezing in the upper regions of the glacier bed. This would support the view of Souchez and others (1988) that pressure-melting and regelation underneath Bylot Island glaciers may occur in zones of high basal stress, such as along steep valley heads. Yet, the discontinuous aspect of the dirty basal ice layers also implies that the accretion process operates not continually but episodically.

\section{SUMMARY AND GONCLUSIONS}

The contrasting bulk volume and texture of the basal debris load of Aktineq and B-7 Glaciers are most likely related to the extent of their respective drainage systems. This implies that subglacial entrainment of debris in zones of confluent ice flow over the alpine uplands may account for much of the total basal load. Our mineralogical data reveal no systematic down-glacier pattern of mixing between basal debris derived from bedrock sources in the Archean uplands and the Cretaceous-Tertiary lowlands. Evidence for accretion of smectite-rich material is restricted to a marginal zone near the glaciers' termini, where it may proceed through net freeze-on of unconsolidated debris at the sole. Other processes, such as the overriding of abandoned subglacial channel beds, are likely to be involved as well.

The textural and isotopic characteristics of the discrete dirty-ice layers in the basal zone of B-7 Glacier are compatible with an accretion process involving basal melting-refreezing at the bed. Assuming that this also applies to Aktineq Glacier, we infer that debris entrainment under the upper reaches of the glaciers occurs in part by regelation in zones of intense basal stress such as along steep bed gradients. Deformation of the newly accreted basal ice around bedrock obstacles may allow for such layers to be preserved well above the glacier sole. The superimposition of contrasting basal ice facies at the ice margin is also consistent with the combination of regelation and marginal debris accretion processes, as advocated by Knight (1994). These conclusions may apply to other sub-polar glaciers, but the efficiency of any given entrainment mechanism is likely to differ as a function of their specific physical setting and thermal regime.

\section{AGKNOWLEDGEMENTS}

This project was supported by National Science and Engineering Research Council grants 010-5682 and 0102546 held by W. Shilts and F. Michel. Logistical support was provided by the Geological Survey of Canada (GSG), the Polar Continental Shelf Project and the Northern Scientific Training Program. Analytical work was conducted with the help of K. Torrance and R. Conlon Carleton University), N. Morrisset Ottawa-Carleton Stable Isotope Facility) and P. Lindsay (sedimentology laboratory, GSC). R. DiLabio (GSC) kindly supplied some unpublished data. We are grateful for reviews by $\mathrm{P}$. Knight, V. Pohjola and R. Souchez, and for useful comments by P. Johnson and C. Burn. We also thank the community of Pond Inlet for their assistance and hospitality.

\section{REFERENCES}

Berry, R.W. 1987. Mineralogical and particle size analysis of Leda clay samples: analytical lechniques. Ottawa, Carleton University. Department of Geography. Geotechnical Science Laboratories. (Report 13.)

Boulton, G.S. 1970. On the origin and transport of englacial debris in Svalbard glaciers. J. Glaciol., 9 (56), 213229.

Boulton, G.S. 1978. Boulder shapes and grain-size distributions as 
indicators of transport paths through a glacier and till genesis. Sedimentology), 25 6), 773-799.

Burn, C.R. and M.G. Maxwell. 1992. Proper determination of the $\delta^{18} \mathrm{O}-\delta \mathrm{D}$ relationship for ice and water by least-squares cubic regression. Can. J. Earth Sci., 30 1), 109-112.

Carroll, D. 1970. Clay minerals: a guide to their X-ray identification. Geol. Soc. Am. Spec. Pap. 126.

DiLabio, R. N. W. and W. W. Shilts. 1979. Composition and dispersal of debris by modern glaciers, Bylot Island, Canada. In Schlüchter, C.. ed. Moraines and varves: origin/genesis/classification. Rotterdam, A.A. Balkema, 145-155.

Gordon, J.E., W. G. Darling, W. B. Whalley and A. F. Gellatly. 1988 $\delta \mathrm{D}-\delta^{18} \mathrm{O}$ relationships and the thermal history of basal ice near the margins of two glaciers in Lyngen, north Norway. F. Glaciol. 34(118), $265-268$.

Griffin, G. M. 1971. Interpretation of X-ray diffraction data. In Carver, R.E., ed. Procedures in sedimentary petrology. New York, John Wiley and Sons, 541569.

Haldorsen, S. 1981. Grain-size distribution of subglacial till and its relation to glacial crushing and abrasion. Boreas, 10 1), 91-105.

Hubbard, B. and M. Sharp. 1989. Basal ice formation and deformation: a review. Prog. Phys. Geogr., 13 (4), 529-558.

Hubbard, B. and M. Sharp. 1993. Weertman regelation, multiple refreezing events and the isotopic evolution of the basal ice layer. $\mathcal{F}$. Glaciol., 39132), 275-291.

Iverson, N. R. 1993. Regelation of ice through debris at glacier beds: implications for sediment transport. Geology, 21 6), 559-562.

Jackson, G. D., A. Davidson and W. C. Morgan. 1975. Geology of the Pond Inlet map-area, Baffin Island, District of Franklin. Geol. Surv. Can. Pap. 74-25.

Jouzel, J. and R. A. Souchez. 1982. Melting refreezing at the glacier sole and the isotopic composition of the ice. F. Glaciol., 28 98), 35-42.

Klassen, R. A. 1985. An outline of glacial history of Bylot Island, District of Franklin, N.W.T. In Andrews, J.T., ed. Quatemary environments: eastern Canadian Arctic, Baffin Bay and western Greenland. London, Allen and Unwin, 428460.
Klassen, R. A. 1993. Quaternary geology and glacial history of Bylot Island, Northwest Territories. Geol. Surv. Can. Mem. 429.

Knight, P. G. 1989. Stacking of basal debris layers without bulk freezingon: isotopic evidence from West Greenland. J. Glaciol., 35 120), 214 216.

Knight, P. G. 1994. Two-facies interpretation of the basal layer of the Greenland ice sheet contributes to a unified model of basal ice formation. Geology, 22 (11), 971-974.

Lawson, D. E. 1979. A sedimentological analysis of the western terminus region of the Matanuska Glacier, Alaska. CRREL. Rep. 79-9.

Lorrain, R. D., R. A. Souchez and J. L. Tison. 1981. Characteristics of basal ice from two outlet glaciers in the Canadian Arcticimplications for glacier erosion. Project 750063. Geol. Surv. Can. Pap. 81-1B, 137-144.

McCuaig, S. J. 1994. Glacial chronology of the South Bylot and Salmon River Lowlands, N.W.T., using erratic dispersal patterns, cosmogenic dating and lichenometry. M.Sc, thesis, Carleton University.

Miall, A.D., H. R. Balkwill and W.S. Hopkins, Jr. 1980. Cretaceous and Tertiary sediments of Eclipse Trough, Bylot Island area, Arctic Canada, and their regional setting. Geol. Surr. Can. Pap. 79-23.

Souchez, R. A. and J. Jouzel. 1984. On the isotopic composition in $\delta \mathrm{D}$ and $\delta^{18} \mathrm{O}$ of water and ice during freezing. J. Glaciol., 30 (106), 369372.

Souchez, R., R. Lorrain, J. L. Tison and J. Jouzel. 1988. Co-isotopic signature of two mechanisms of basal-ice formation in Arctic outlet glaciers. Am. Glaciol., 10, 163-166.

Sugden, D. E. and 6 others. 1987. Evidence for two zones of debris entrainment beneath the Greenland ice sheet. Nature, 328 6127), $238-241$.

Velde, B. 1985. Clay minerals: a physico-chemical explanation of their occurrence. Rotterdam, Elsevier.

Weertman, J. 1961. Mechanism for the formation of inner moraines found near the edge of cold ice caps and ice sheets. f. Glaciol., 3 (30), 965-978. 